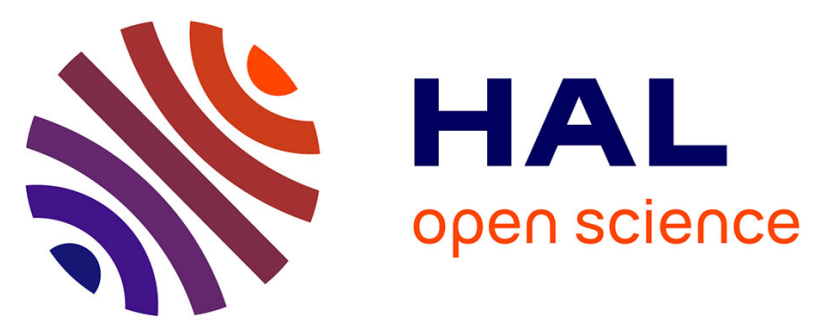

\title{
Sustainable Economic Development and High Quality Engineering Education: Correlating Factors in Brazil's Macro Regions
}

Vitor Mendes Caldana, Márcia Silva

\section{- To cite this version:}

Vitor Mendes Caldana, Márcia Silva. Sustainable Economic Development and High Quality Engineering Education: Correlating Factors in Brazil's Macro Regions. IFIP International Conference on Advances in Production Management Systems (APMS), Sep 2016, Iguassu Falls, Brazil. pp.398-405, 10.1007/978-3-319-51133-7_47 . hal-01615768

\author{
HAL Id: hal-01615768 \\ https://hal.inria.fr/hal-01615768
}

Submitted on 12 Oct 2017

HAL is a multi-disciplinary open access archive for the deposit and dissemination of scientific research documents, whether they are published or not. The documents may come from teaching and research institutions in France or abroad, or from public or private research centers.
L'archive ouverte pluridisciplinaire HAL, est destinée au dépôt et à la diffusion de documents scientifiques de niveau recherche, publiés ou non, émanant des établissements d'enseignement et de recherche français ou étrangers, des laboratoires publics ou privés.

\section{(c)(1)}

Distributed under a Creative Commons Attribution| 4.0 International License 


\title{
Sustainable Economic Development and High Quality Engineering Education: Correlating Factors in Brazil's Macro Regions
}

\author{
Vitor Mendes Caldana ${ }^{12}$, Márcia Terra da Silva ${ }^{2}$ \\ 1 IFSP, Santana de Parnaíba, Brazil \\ vitor.caldana@ifsp.edu.br \\ 2 Paulista University, São Paulo, Brazil \\ marcia.terra@uol.com.br
}

\begin{abstract}
GDP development over time is one method of measuring the economic evolution of a country. According to the OECD, there are several factors that can influence GDP, one of which is Engineering Education. A possible way to determine the potential for economic development would be assessing the performance of high-level education, especially if the GDP-Engineering correlation is taken into account. Studies were overtaken to study the lack of engineering in Brazil as a structural problem. However, there is no analysis about the regional factor and the engineering education performance. The objective of this paper is to assess if there is a correlation between the regional GDP and good performance Engineering Education in Brazil. The study is based on official data provided by governmental organizations. A conclusion is reached were the regional disparity in GDP is similar to the disparity on High Quality Engineering Education.
\end{abstract}

Keywords: Economic development $\cdot$ Regional development $\cdot$ Engineering Education

\section{Introduction}

Brazil is the seventh biggest economy in the world; however due to the continental dimensions of the country $\left(8,515,767 \mathrm{~km}^{2}\right)$ there is a great challenge to equally develop all the regions. Global Brazil's Gross Domestic Product (GDP) has had an increase of a $5.27 \%$ on average in the last 20 years. In this period, the annual increase has not been consistent. This shows that Brazil's GDP growth results are inconsistent facing big fluctuations when compared to the average growth [1].

The GDP results also showed that the regional disparity is still significant, as shown in Table 1.

The GDP percentage participation of the regions, aligned with the GDP and GDP per capita retraction scenario shows the challenge to equally develop regions. 
Table 1. Macro-Regions GDP Participation. Source: [2]

\begin{tabular}{cc}
\hline Macro Region GDP Percentage \\
\hline Central-West & $9,60 \%$ \\
Northeast & $13,40 \%$ \\
North & $5,40 \%$ \\
Southeast & $65,20 \%$ \\
South & $16,20 \%$ \\
\hline
\end{tabular}

For that, according to Lins [3], there is a direct correlation observed by the Organization for Economic Co-operation and Development (OECD) in terms of Human Resources in Science and Technology (HRST) and GDP. The discussion of sustainable regional development is a pressing issue [4,5], and is met with similar concern on the development of expertise $[5,6]$.

This study correlates the regional factor on the GDP percentage participation and the performance of reginal engineering education. The objective of this work is to compare the recent results in GDP with the current engineering education performance and try to verify if there is a correlation between both.

\section{Methodology}

This work is an analysis of bibliographical references and governmental data. It is a research to better understand the impact of Higher Education Institutions (HEIs) in engineering on regional GDP.

Recent studies conducted to analyze the lack of engineers were influenced by parameters suggested by Butz [7]. Butz proposed five parameters to measure the shortage of products. This can be adapted to be understood as "production of high performance engineers" if necessary considerations are made. The parameters suggested by Butz are:

- Production is lower than in recent past.

- Leader's market share has been increasing over time.

- Production is lower than what expected by the suppliers.

- Production is lower than what expected by society.

- Production does not meet market needs, which can be demonstrated by ascending prices.

Another study made by Nascimento [8] included specific parameters for understanding the lack of engineers. He understood that the parameters suggested by Butz were not specific to deal with the issue of skill shortage and proposed the following adaptations:

- Low unemployment rates.

- Rising proportion of graduates taking typical occupations on the area. 
- High job rotation between engineers, what suggests they receive job offers from the competition or different business with better employment conditions.

- New job positions are difficult to be filled.

- Increase in working hours.

- High competition between companies for the top professional.

- Reduction in hiring demands.

Based on both the parameters from Butz [7] and Nascimento [8], Lins et al. [3] conducted a study of lack of engineers. The parameters selected by Lins et al [3] for the study, properly adapted to the case study, were:

1. The number of engineering graduates is lower than in the past.

2. The number of engineering graduates is lower than expected.

3. The number of engineering graduates is lower than what would be needed by the market, which would reflect on an escalation of salary.

4. Low unemployment percentages among engineers than in the past.

5. Increase in number of engineers working among the typical professions from the past.

6. High job rotation between engineers, what suggests they receive job offers from the competition or different business with better employment conditions.

Using those parameters, the conclusion was that Brazil doesn't have a structural lack of engineers. Even though the consensus is that the lack of engineers is not a structural issue, there are variables on the analysis of the study that showed a positive indication towards it (parameters 3,4 and 5). The studies also do not investigate the regional factor, in which different regions and different clusters may have a very specific need for technical background, as well as do not take into consideration the quality factor of the degrees - although mentioned - and the curriculum design. The studies also do not reach a conclusion as to why, according to Maciente and Araújo [9], only $38 \%$ of graduates remain with their main occupation as engineers.

This paper will focus on the discussion of better understanding if the results of regional GDP and HEI's point to a regional lack of engineers, if the regional GDP and HEI's results are similar and if Engineering Education can affect a sustainable development scenario.

To continue the discussion of this paper, we will take a closer look on the factors of high-level education engineering schools performance, curriculum design, the roles of academia in regional development and the development of expertise.

\section{Data Analysis and Bibliographical Review}

\subsection{High Level Education Engineering Performance}

Brazil has a performance exam of high education named ENADE (Nacional Exam of Student Performance). The result from ENADE evaluates graduation 
students on a grade from 1 to 5 , with 5 being the highest score. There is also a SC concept that is given to HEIs that do not have at least two graduates taking the exam in that term, which is common on new approved universities. The exam is annual however, due to the number of different careers and HEIs, each one is evaluated every three years.

ENADE takes into consideration both specific and general performance. The general graduation curriculum represents $25 \%$ of the total grade and the specific represents $75 \%$. After calculating the average grade and standard deviation for each particular HEIs, the method than calculates the average and standard deviation of all HEIs in that specific area that took the test to standardize the grade in all Brazil [10].

According to ENADE the number of engineer graduates who took the test rose from 25,657 in 2008 to 46,675 in 2011 . Only $20 \%$ of the graduates received grades 4 and 5 in 2011, with a significant decrease from 2008 when the result was $29 \%$. The increase of number of participants does not indicate necessarily an increase of number of graduates, as the exam has been gaining importance as the years pass.

Table 2. Number of Engineering HEIs per region and ENADE results in 2011

\begin{tabular}{cccccccc}
\hline \multirow{2}{*}{ Region } & \multicolumn{9}{c}{ Engineering Schools } \\
& 1 & 2 & 3 & 4 & 5 & SC & Total \\
\hline Central-West & 6 & 13 & 17 & 12 & 3 & 8 & 59 \\
Northeast & 11 & 41 & 50 & 34 & 4 & 21 & 161 \\
North & 5 & 19 & 19 & 4 & 0 & 25 & 72 \\
Southeast & 36 & 197 & 176 & 84 & 43 & 82 & 618 \\
South & 7 & 44 & 96 & 59 & 15 & 38 & 259 \\
\hline
\end{tabular}

Good performance evaluation is considered on grades 4 and 5 . With that parameter, we can see that southeast has the biggest amount of schools (127 or $49 \%$ ). The values shows a decrease in HEIs with grade 1, that can be explained by both evolution of grade and also closure of some institutions, as consecutive 1 results will cause the HEI to close, according to ENADE policy. The evolution of quantity of HEIs with grade $2(2.28 \%), 3(25.61 \%)$ and $4(33.10 \%)$ shows not only new institutions; a deeper look at the database shows an increase in institutions quality, with HEIs being able to increase their test scores over the three evaluations. The biggest warning comes from the significant reduction of 5 grade: $25.29 \%$. This value can only be explained by the decrease in education performance [11].

The low percentage of high performance HEIs $(22.07 \%)$ can be a determinant factor as to why engineer graduates can't keep jobs in their typical applications as they lack the necessary specific knowledge to perform properly. 


\subsection{Curriculum Design}

The standard curriculum design is still not what the market expects according to Lansu. He proposes a method of developing the design based on an interactive workshop, divided in two rounds in which the key actors of each region would unite to formally discuss and reach a consensus on the necessary design for that region. The study is consistent with the idea that graduates must have the qualifications desired by their region. Bringing the industry as a consultant to properly design the curriculum of the career, especially on cases such as engineering, will bring a better understanding of the needs for development [12].

Another positive factor is the possibility of keeping the graduate in the region through local employment. This supports the regional scenario without the need of migration to seek job opportunities, allowing continuous and sustainable development. Through the continuous "upgrade" of the curriculum design and the necessary adaptation of the industries demands each region will get the necessary professionals to proper develop such region. That being said, it is important to notice that the needs from regions can be significantly different from each other, as described by the Central-west example of high participation of agroindustry or the Northeast tourism industry.

There are also other examples of adaptive curriculum, in cases as analyzed by Avard and Zenios in the case study of the Polytechnic of Namibia where core competences such as Networked Learning, Innovation and Problem solved based learning were introduced in the curriculum. Even though not utilizing the process proposed by Lansu, it generates a result from an established analysis of the market and the needs for specific graduation curriculum [13].

Curriculum Design is also a factor that would remove engineers from the typical applications jobs, as even though the student might even have a good performance on the course, the curriculum itself is not what is expected by the market and thus the candidate still is unable to develop properly in the profession due to an unmatched skill set.

\subsection{Roles of Academia in Regional Development}

Following the creation by OECD of the "Supporting the Contribution of HighLevel Educational Institutions in Regional Development" program, studies were implemented to establish what roles and what contributions academia could give to regional development.

There are several roles that the academia can play according to the study made by Devine-Wright to support regional development [14]. According to Stephens et al, the main contribution is educational and training activities. Universities can also contribute in various forms to help the regional development [15].

According to the study made by Zilahy and Huisingh, some significant obstacles are present. The major obstacles are lack of understanding of concepts of Sustainable Development, lack of clear vision and objectives; lack of commitment; conflicting interests; lack of information about the regional activities; lack 
of leadership; high organizational costs and lack of sufficient funding. Those obstacles justify as to why the majority perception of academics, $70 \%$, still believe that the participation of academia in regional sustainable initiatives is still not sufficient [16].

Oliveira also contributes to this idea, specially taking into consideration what he proposes as "learning region". It would be the role of academia to implement, with help from local and political actors, an environment that would allow research and development to evolve regions from an exploratory context to a development context. With an innovation scenario present, with help from academia to produce the necessary expertise, the region would enter in a potent development self-sufficient circle [4].

\subsection{Development of Expertise}

The development of expertise is fundamental as a method of training and continuous upgrading workforce capacity to deal with new and unseen difficulties. It is a corner stone for regional development as it allows regions to innovate to achieve goals [5].

Sgobbi and Cainarca demonstrated on their research, conducted by 1,800 interviews, that the high-performance work practices - HPWPs - are conducted by high-performance professional [17]. However, the growth in core wage is inconclusive unless other aspects are accounted for. Not only high performance but a series of other skills that are growing in importance in Engineering Education to supplement this finding, such as the factor described by Avard and Zenios [13].

Litzinger reached a conclusion that is fundamental to align the curriculum and the teaching skill/methods [6]. This can be done in several ways; however, the expected outcome will be the development of the necessary expertise to properly prepare the graduate to be able to produce in the region, raising his wage and thus the GDP per capita.

Ultimately, the generation of expertise will be responsible for several enhancements not only in better HEIs, but also in a networking standpoint between academia and industry. Through this enhanced expertise it is possible to introduce the "learning regions" proposed by de Oliveira [4] and achieve a solid and virtuous cycle of development.

\section{Results}

It is possible to notice in Figure 1 that the difference in regional GDP is significant. It also shows a disparity that is consistent with the relation between economic development and quantity of graduates from HEIs with good performance, thus showing a challenging scenario to achieve a sustainable and constant growth of Brazil's regions. The conclusion by Litzinger also point to generation of expertise as a mutual process between HEIs and the industry that can profit both $[6]$. 


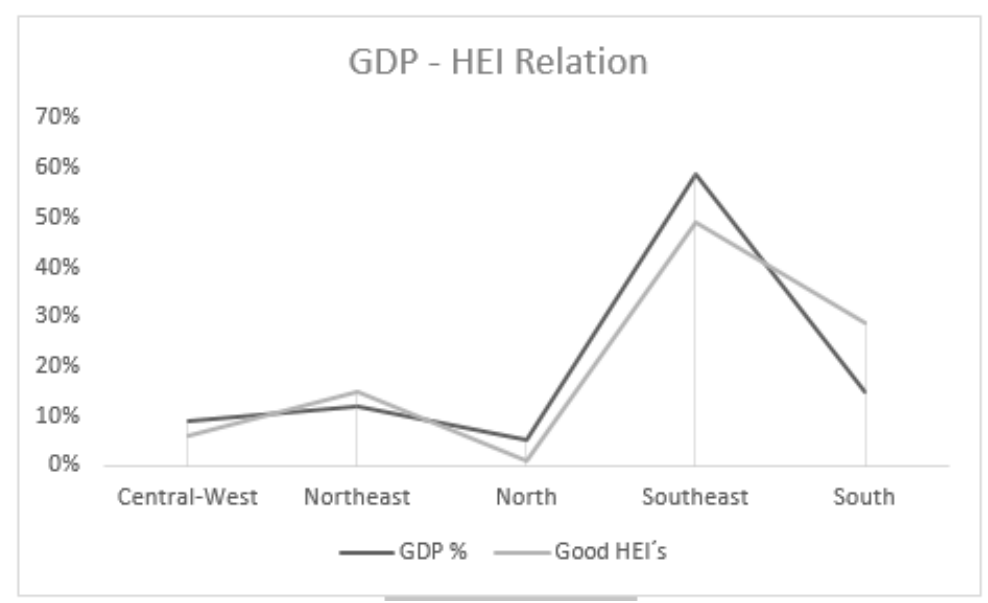

Fig. 1. GDP - HEI Performance

\section{Conclusions and Outlook}

Analyzing the difference in regional contribution of the national GDP, as shown in Table 1, it is clear that there is a significant disparity and the challenge is even bigger considering the difference between the industrialization level and the quantity and quality of the universities from the different regions as shown in Table 2.

Concerning the quantity of engineering degrees, there's been an increase in number of universities, which will lead to an increase in total number of graduates. The quality factor however has declined as shown especially at the $25.29 \%$ decrease of grade 5 ("State of the Art") Engineering Education Universities.

It is important to bring forth mechanisms to further include the academia in regional development. Several policies and actions can be taken by both sides (academia and regional actors) to enhance their participation and further increase the bond between them.

It is clear that the lack of engineers on the regions and the low occupation rate have a direct impact on the regions as shown by the proximity of the GDP percentage and the quantity of quality of degrees. It is also possible to asses from Figure 1 that the High Quality Engineering HEI's and the GDP have very similar behavior between the macro regions.

To finalize, the sources quoted enforce the need for innovation and technical background as fundamental to regional development, especially if the cluster mode and academia fomented research is to be installed as an alternative for sustainable development. 


\section{References}

1. do Brasil, B.C.: Time Series Management System, https://www3. bcb.gov.br/sgspub/localizarseries/localizarSeries.do?method= prepararTelaLocalizarSeries

2. IBGE: Contas Nacionais Trimestrais, ftp://ftp.ibge.gov.br/Contas_ Nacionais/Contas_Nacionais_Trimestrais/Fasciculo_Indicadores_IBGE/ pib-vol-val_201404caderno.pdf.

3. Lins, L.M., Salerno, M.S., Araújo, B.C., Gomes, L.A.V., Nascimento, P.A.M.M., Toledo, D.: Escassez de Engenheiros no Brasil? Uma Proposta de Sistematização do Debate. Novos Estudos - CEBRAP (98), 43-67 (2014)

4. Oliveira, G.B.: Regiões Inteligentes como Estratégia de Desenvolvimento Local. Revista Orbis Latina 1(1), 35-39 (2011)

5. Quandt, C.O.: Inovação e Território: Elementos para a Formulação de Políticas de Capacitação Tecnológica e Desenvolvimento Regional. CMDE/UFPR, Curitiba

6. Litzinger, T., Lattuca, L.R., Hadgraft, R., Newstetter, W.: Engineering Education and the Development of Expertise. Journal of Engineering Education 100(1), 123$150(2011)$

7. Butz, W., Bloom, G., Gross, M., Kelly, K., Kofner, A., Rippen, H.: Is There a Shortage of Scientists and Engineers? How Would We Know? (2003)

8. Nascimento, P.A.M.M.: Há Escassez Generalizada de Profissionais de Carreiras Técnico-Científicas no Brasil? : Uma Análise a Partir de Dados do CAGED. Mercado de Trabalho pp. 19-28 (2011)

9. Maciente, A., Araújo, T.: A Demanda por Engenheiros e Profissionais Afins no Mercado de Trabalho Atual. Radar Brasília pp. 43-54 (2011)

10. INEP: Relatório Síntese, http://portal.inep.gov.br/web/guest/enade/ relatorio-sintese-2011

11. INEP: Enade, http://portal.inep.gov.br/enade

12. Lansu, A., Boon, J., Sloep, P.B., van Dam-Mieras, R.: Changing professional demands in sustainable regional development: a curriculum design process to meet transboundary competence. Journal of Cleaner Production 49, 123-133 (2013)

13. Avard, G., Zenios, M.: Curriculum Framework Considerations for Introducing Networked Learning within a Career-Focused Higher Education Institution. In: Proceedings of the 8th International Conference on Networked Learning. pp. 1-9. Maastricht School of Management, Maastricht (2012)

14. Devine-Wright, P., Fleming, P.D., Chadwick, H.: Role of Social Capital in Advancing Regional Sustainable Development. Impact Assessment and Project Appraisal 19(2), 161-167 (2001)

15. Stephens, J.C., Hernandez, M.E., Román, M., Graham, A.C., Scholz, R.W.: Higher Education as a Change Agent for Sustainability in Different Cultures and Contexts. International Journal of Sustainability in Higher Education 9(3), 317-338 (2008)

16. Zilahy, G., Huisingh, D.: The Roles of Academia in Regional Sustainability Initiatives. Journal of Cleaner Production 17(12), 1057-1066 (2009)

17. Sgobbi, F., Cainarca, G.C.: High-Performance Work Practices and Core Employee Wages: Evidence from Italian Manufacturing Plants. ILR Review 68(2), 426-456 (2015) 